\title{
Efficiency Evaluation of Russia Regions Economy Digital Transformation
}

\author{
Elshin L.A. \\ Department of Economics \\ University of management "TISBI" \\ Kazan, Russia \\ Leonid.Elshin@tatar.ru
}

Faizrakhmanova E.A.

Department of Economics

University of management "TISBI"

Kazan, Russia

el.faizr@mail.ru

\author{
Savushkin M.V. \\ Department of Economics \\ University of management "TISBI" \\ Kazan, Russia \\ savushkinmv@mail.ru
}

\author{
Gusarova V.U. \\ Department of economic theory and innovation \\ University of management "TISBI" \\ Kazan, Russia \\ vgusarova@mail.ru
}

\begin{abstract}
Digital transformation breaks the settled models of functioning of economic entities and forms basis of perspective competitive development of economic systems in the current and future conditions of the global social and economic environment. The markets which are most actively adapting to new conditions of digital revolution form basis of sustainable development for the long decades ahead. In this regard monitoring and assessment of level and quality of digitalization of the socioeconomic environment characterizes the potential of their sustainable and competitive development within world economy into the development waterway corresponding to the sixth technology way. The algorithm of measurement of the development level of substantial elements of digital economy in regions of the Russian Federation is suggested in this research. The distinctive aspect giving uniqueness to the developed algorithm is orientation of the developed instruments to a research of five main directions of digitalization determined by the order of the Government of the Russian Federation of 28.07.2017 (No. 1632-r): "standard regulation", "personnel for digital economy", "forming of research competences and technology reserves", "information infrastructure", "information security". By results of a research the principal components characterizing qualitative and quantitative parameters of efficiency of program implementation "Digital economy of the Russian Federation" in the regions of Russia are revealed, the interrelation the defining efficiency of development of digital economy of the region from the level of its economic development is established.
\end{abstract}

Keywords-digital economy; region; competitiveness; technology ways; efficiency of development; economic growth.

\section{INTRODUCTION}

Digitalization of economic processes actively infiltrate into the system of the economic relations of Russia, defining the corresponding forms of business processes and forming of social models of development. Trends of this sort directly determine the level of competitiveness of national economy in the conditions of globalization of reproduction processes. In this regard the research of the factors, both an institutional, and tactical order forming parameters of digitalization of the socioeconomic environment represents extremely relevant and demanded direction in modern science.

Diffusion and activization of processes of elements integration of digital economy into the economic systems becomes a necessary condition for a country reaching a new level of the technology development corresponding to the sixth technological way. According to it the new basis of economic growth of the state will be formed in the next 20-30 years within information technology development, superfast digital telecommunications, a nanoelectronics, global intellectual information networks providing effective development and reproduction of a human capital, development of progressive managerial technologies.

According to the data published by McKinsey Global Institute (MGI) [1] during next 20 years up to $50 \%$ of jobs in the world will become automated. This effect caused by transformation and digitalization of economic processes will be comparable by the scale with forming of the second and third technology ways of development of world economy which predetermined powerful industrial breakthrough of evolutionary development of humanity. The countries which organically became a part of the trend of industrial revolution of that period made their economies superior in world economy for many years and decades.

Today, at a boundary of the sixth technology way of the fourth industrial revolution (dated from 2015-2020 to 20452050) absolutely new forms of economic growth define leadership and competitiveness of development of national economies. Russia gets an opportunity for transition to new 
basis of social and economic development within approaching digital revolution possessing the high level of the innovation potential, the competitive quality level of a human capital, availability of rich resource base.

The research relevance of digitalization development of the socioeconomic environment dictates need of complex and systems analysis of digital transformation both on micro and at the macrolevel. At the same time the questions connected with identification of the factors and parameters estimating prospects and trends of digitalization of economy are important.

\section{LITERATURE REVIEW}

In economic literature it is possible to meet various approaches to the solution of similar questions [1, 2, 3, 4, 5, 6, $7,8]$. More they rely on systematization and processing of the statistics estimating the level of development of digital infrastructure of territories.

In general, analyzing approaches of Russian experts to assessment of digitalization level of economy, it is necessary to allocate a number of the works with methodical approaches to a research of the question and subsequently found the approbation on the example of the Russian economic system and its regions.

The Ministry of digital development, communication and mass communications of the Russian Federation developed index evaluating regions of the Russian Federation on the level of development of an informational society in regions [10]. The technique includes digitalization level evaluation on 120 indicators grouped in the uniform groups forming a basis for determination of 17 subindexes. Main goal of the developed methodical approach is systematic monitoring of efficiency of program implementation of the Russian Federation "An informational society (2011-2020)". The main results of a research for 2016, 2017 are given in table 1.

TABLE I. RATING OF THE REGIONS BY THE LEVEL OF INFORMATIZATION [10]

\begin{tabular}{|c|c|c|c|}
\hline № & Region & Place in 2016 & Place in 2017 \\
\hline 1 & Moscow & 1 & 1 \\
\hline 2 & Tyumen region & 6 & 2 \\
\hline 3 & $\begin{array}{c}\text { Khanty-Mansi autonomous } \\
\text { district Yugra }\end{array}$ & 3 & 3 \\
\hline 4 & Republic of Tatarstan & 11 & 4 \\
\hline 5 & Tula region & 34 & 5 \\
\hline 6 & Novosibirsk region & 7 & 6 \\
\hline 7 & Republic of Bashkortostan & 31 & 7 \\
\hline 8 & Yamalo-Nenets Autonomous & 4 & 8 \\
\hline 9 & Area & 18 & 9 \\
\hline 10 & Tomsk region & 24 & 10 \\
\hline
\end{tabular}

Moscow School of Management Skolkovo offered the integrated approach allowing to estimate the level of use of potential of digital technologies in all aspects of economic activity through the generalizing integrated index. To increase the accuracy of assessment in a research seven subindexes are used with mark assessment of the index [10]. According to it integrated assessment of capacity of regions is performed on the basis of symbiosis of statistical parameters and also the qualitative, evaluated by results of the complex analysis information open resources signaling about the facts and events in the sphere of development of digital transformation of infrastructure of regional economic systems [11,12]. Data of rating Skolkovo "Digital Russia" are provided in table 2.

TABLE II. THE RATING OF TERRITORIAL SUBJECTS OF THE RUSSIAN FEDERATION ON THE LEVEL OF DIGITALIZATION [11]

\begin{tabular}{|c|c|c|c|}
\hline № & $\begin{array}{c}\text { Territorial subject of the Russian } \\
\text { Federation }\end{array}$ & $\begin{array}{c}\text { I half-year of } \\
2018\end{array}$ & 2017 \\
\hline 1 & Moscow & 75,14 & 70,01 \\
\hline 2 & Republic of Tatarstan & 74,74 & 67,95 \\
\hline 3 & St. Petersburg & 74,55 & 67,54 \\
\hline 4 & KhMAO-Yugra & 74,24 & 67,88 \\
\hline 5 & Tyumen region & 74,01 & 65,44 \\
\hline 6 & YANAO & 72,43 & 66,03 \\
\hline 7 & Moscow region & 71,86 & 65,61 \\
\hline 8 & Republic of Bashkortostan & 71,29 & 65,08 \\
\hline 9 & Leningrad Region & 71,25 & 62,45 \\
\hline 10 & Chelyabinsk region & 70,75 & 59,81 \\
\hline
\end{tabular}

The main benefit of this technique is an opportunity to calculate the index of digitalization as the complex generalized parameter including both quantitative, and qualitative parameters of processes of digitalization.

The rating is the first measurement of a state and dynamics of digitalization in Russia.

\section{RESEARCH METHODOLOGY}

It is important to note that each of above ratings is focused on quantitative assessment of level of digital transformation of regions of the Russian Federation proceeding from inspection of a wide range of the information statistical data characterizing various components of digitalization of the socioeconomic environment. Undoubtedly, this sort the analysis forms representation of rather regional differentiation and potential of social and economic development of territorial subjects of the federation in the conditions of entry of the Russian economy into so-called fourth industrial revolution.

At the same time, we consider it expedient to add this range of researches and estimates with development and approbation of the methodical approaches forming a basis for the rating of regions which concentrated only on five main directions of digitalization of national economy of the Russian Federation and determined by the order of the Government of the Russian Federation of 28.07.2017 (No. 1632-r). According to this law since 2017 in Russia the Digital Economy of the Russian Federation program has been held according to which 5 main priority directions of development are implemented:

- Standard regulation;

- Personnel for digital economy; 
где $\mathrm{I} \_\mathrm{j}$ - value of the subindex,

- Forming of research and technology competences;

- Information infrastructure;

- Information security.

\section{RESULTS}

The purpose of work is creation of an algorithm of determination of indexes which display condition of the region in each of the above-mentioned directions with the subsequent assessment of the aggregated value of the integrated index counted as the "weighed" amount of the received five subindexes.

Taking into account the available statistical base and also regional specifics the list of the indicators was defined in calculation base in the identified directions of a research.

It is important to note that the choice of a system of the indicators which are used in further calculations is caused by their belonging to the corresponding direction established by the Digital Economy of the Russian Federation Program. The chosen system of indicators belongs only to the category of indicators of statistical order and it is defined on the basis of data of Monitoring of development of an information society in the Russian Federation

According to the approaches given above, at the heart of methodical instruments the index method of aggregation and ordering of statistical information is mortgaged. As a settlement period annual data for 2013-2017 was used.

The passed values of time series are restored with use of the IBM SPSS Statistics program. (The analysis of the passed values).

The standardization of initial indicators is carried out for comparability of data (regulation).

The following formula is applied for the indicators stimulators, i.e. indicators which growth of values leads to improvement of a condition of the region in the designated direction:

$x \_i=\left(x \_i-x \_\right.$min $) /\left(x \_\right.$max-x_min $)$, where

$x \_i$ - current value of a time series,

x_max- maximum value of a row,

x_min- minimum value.

For indicators - destimulyators which growth, on the contrary, leads to the deterioration in general state, calculation was made with the formula:

$x \_i=\left(x \_m a x-x \_i\right) /\left(x \_m a x-x \_\right.$min $)$, where

$x \_i$ - current value of a time series,

x_max- maximum value of a row,

x_min- minimum value.

The total value of each subindex is calculated by the following formula:

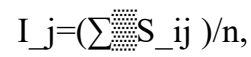

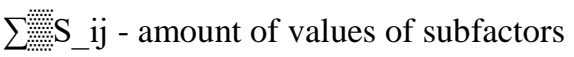

n- number of subfactors.

The index is calculated as the weighed amount of five basic subindexes.

A. Practical significance, proposals and results of implementations, results of experimental studies

Total assessment is performed using integrated criterion:

I_de=I_slr+I_rc+I_is+I_infr+I_per, where

I_de- Digital Economy index,

I_slr- Standard Legal Regulation subindex,

I_is- Information security subindex,

I_rc- Forming of research competences and technical reserves subindex,

I_infr-Information infrastructure subindex,

I_per- Personnel and education subindex.

The results of calculation are presented in tables 3, 4 .

TABLE III. THE FIRST 10 POSITIONS OF RATING ACCORDING TO THE RESULTS OF 2017

\begin{tabular}{|c|c|c|c|c|}
\hline № & Region & 2015 & 2016 & 2017 \\
\hline 1 & Moscow & 0,85 & 0,80 & 0,87 \\
\hline 2 & St. Petersburg & 0,62 & 0,62 & 0,58 \\
\hline 3 & Moscow region & 0,49 & 0,51 & 0,51 \\
\hline 4 & Republic of Tatarstan & 0,50 & 0,52 & 0,46 \\
\hline 5 & Yaroslavl region & 0,50 & 0,53 & 0,45 \\
\hline 6 & Ulyanovsk region & 0,50 & 0,49 & 0,45 \\
\hline 7 & Khabarovsk Krai & 0,49 & 0,52 & 0,44 \\
\hline 8 & Tambov region & 0,46 & 0,49 & 0,44 \\
\hline 9 & Kaluga region & 0,51 & 0,51 & 0,43 \\
\hline 10 & Sverdlovsk region & 0,44 & 0,46 & 0,43 \\
\hline$\ldots$ & $\ldots$ & $\ldots$ & $\ldots$ & $\ldots$ \\
\hline 76 & Republic of Khakassia & 0,36 & 0,39 & 0,29 \\
\hline 77 & $\begin{array}{c}\text { Jewish Autonomous } \\
\text { Region }\end{array}$ & 0,24 & 0,31 & 0,29 \\
\hline 78 & Arkhangelsk region & 0,37 & 0,36 & 0,29 \\
\hline 79 & Republic of Buryatia & 0,34 & 0,36 & 0,28 \\
\hline 80 & Republic of Kalmykia & 0,32 & 0,35 & 0,28 \\
\hline 81 & Republic of Tyva & 0,35 & 0,35 & 0,26 \\
\hline 82 & $\begin{array}{c}\text { Kabardino-Balkar } \\
\text { Republic }\end{array}$ & 0,27 & 0,32 & 0,26 \\
\hline 83 & $\begin{array}{c}\text { Karachay-Cherkess } \\
\text { Republic }\end{array}$ & 0,25 & 0,30 & 0,23 \\
\hline 84 & Republic of Dagestan & 0,19 & 0,28 & 0,22 \\
\hline 85 & Chechen Republic & 0,29 & 0,14 & 0,18 \\
\hline
\end{tabular}




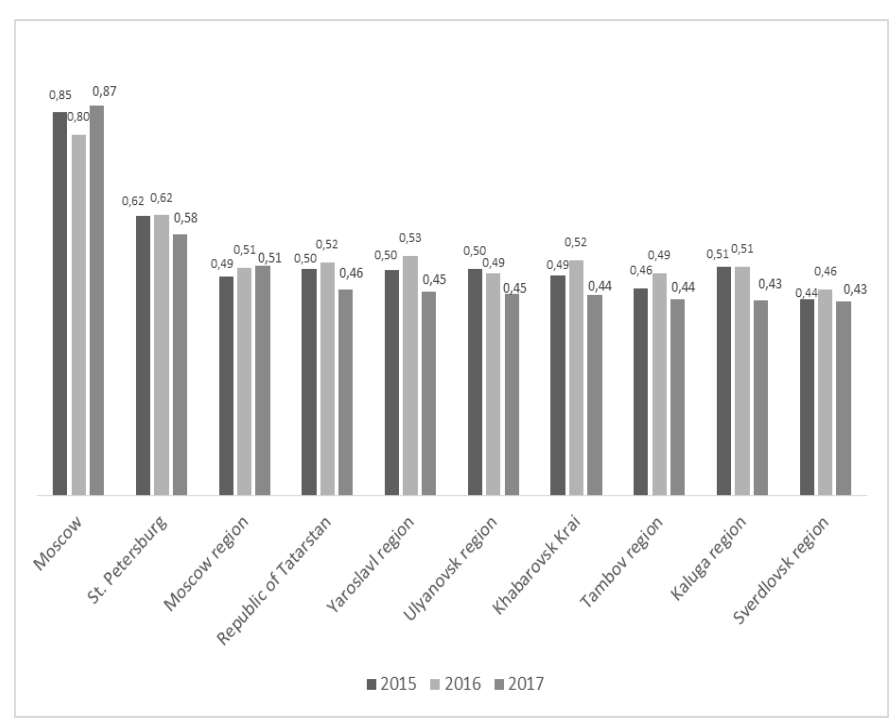

FIg. I. Chart of the Digital Economy index of regions of the Russian Federation (for the first 10 positions)

TABLE IV. DATA OF SUBINDEXES OF FEDERAL DISTRICTS OF THE RUSSIAN FEDERATION

\begin{tabular}{|c|c|c|c|c|}
\hline & $\begin{array}{c}\text { Informa } \\
\text { tion } \\
\text { security }\end{array}$ & $\begin{array}{c}\text { Information } \\
\text { infrastructure }\end{array}$ & $\begin{array}{c}\text { Personnel } \\
\text { and } \\
\text { education }\end{array}$ & $\begin{array}{c}\text { Research } \\
\text { competences }\end{array}$ \\
\hline $\begin{array}{c}\text { Central Federal } \\
\text { District }\end{array}$ & 0,843 & 0,604 & 0,826 & 0,774 \\
\hline $\begin{array}{c}\text { Northwestern } \\
\text { Federal District }\end{array}$ & 0,689 & 0,373 & 0,816 & 0,427 \\
\hline $\begin{array}{c}\text { Southern } \\
\text { Federal District }\end{array}$ & 0,816 & 0,255 & 0,186 & 0,143 \\
\hline $\begin{array}{c}\text { North } \\
\text { Caucasian } \\
\text { Federal District }\end{array}$ & 0,862 & 0,308 & 0,108 & 0,258 \\
\hline $\begin{array}{c}\text { Volga Federal } \\
\text { District }\end{array}$ & 0,732 & 0,261 & 0,588 & 0,641 \\
\hline $\begin{array}{c}\text { Ural Federal } \\
\text { District }\end{array}$ & 0,853 & 0,304 & 0,494 & 0,316 \\
\hline $\begin{array}{c}\text { Siberian Federal } \\
\text { District }\end{array}$ & 0,652 & 0,259 & 0,279 & 0,096 \\
\hline $\begin{array}{c}\text { Far Eastern } \\
\text { Federal District }\end{array}$ & 0,783 & 0,591 & 0,265 & 0,413 \\
\hline
\end{tabular}

Is is necessary to consider not only factors defined earlier but also extent of differentiation of regions on the level of digitalization of economy depending on the size of macroeconomic indicators. In this research we choose an indicator "The gross regional product". Distribution of regions according to the offered concept is introduced in figure 2 .

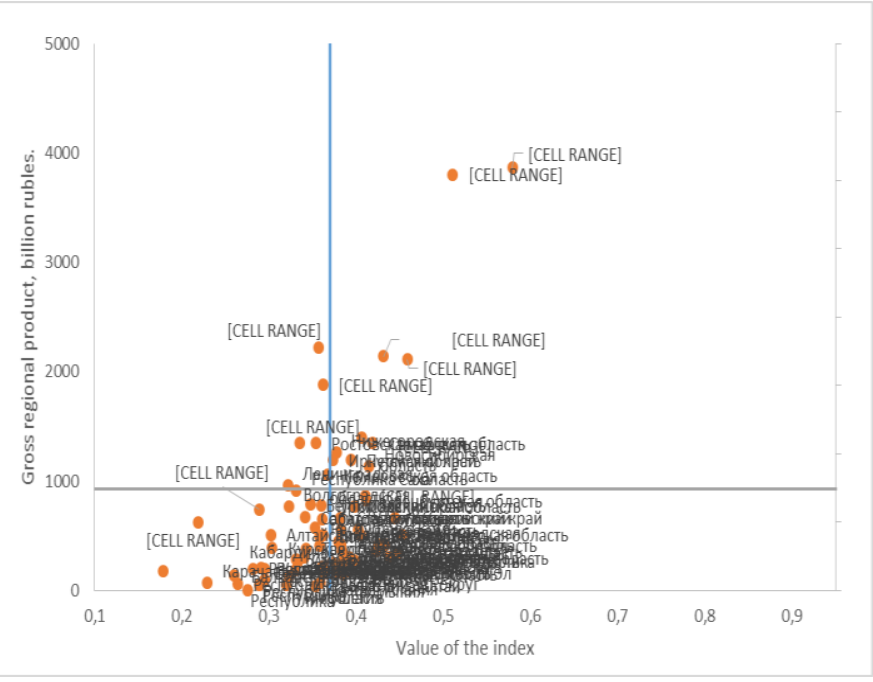

FIG. II. Distribution of regions of the Russian Federation by the VRP level and by value of DE index, 2017

Regions are divided into 4 groups (quadrant). The most backward regions both on digitalization level and on the VRP level are located in a quadrant 1 , and the leading regions are in a quadrant 3 .

\section{DISCUSSION}

The mail conclusion received by the results of this research is that not just the rating of the territorial subjects of the Russia federation in the sphere of digitalization quality of their socioeconomic environment is established, but also the interrelation defining efficiency of development of digital economy of the region from the level of its economic development. So, on the basis of comparison of indicators of GRP and the integrated indicator estimating the level of digitalization of the territorial subject of the federation is defined and the process of digital transformation in regions considerably depends on level and dynamics of a gross regional product. This conclusion forms a basis for development and decision making in the field of public administration in the sphere of regulation and integration into the social and economic environment of regions involved in realization of the key directions of the Digital Economy of the Russian Federation program. It is important to note at the same time that the offered instruments allow to identify weak positions and to define actions providing achievement of objectives and purposes.

\section{CONCLUSIONS}

The evaluation allows to estimate qualitative and quantitative parameters of effective program implementation "Digital economy of the Russian Federation" by five directions and ideas of very differentiated nature of regional development in the sphere of digitalization of the socioeconomic environment. In general it should be noted that the received results considerably coordinate with the results of the researches given above. However the main difference of this work is its orientation only to quality evaluation of digital transformation in regions of the Russian Federation through 
[5] Global innovation index of 2017: Switzerland, Sweden, the Netherlands,

implementation of the efficiency evaluation program "Digital economy of the Russian Federation".

Thanks: the publication is prepared within the supported Russian Federal Property Fund of scientific project No. 18010-00536.

We express gratitude for preparation of article to group of authors of the RNF scientific project (project No. 19-1800202).

\section{References}

[1] A. Aptekman, V. Kalabin. "Digital Russia: new reality" / McKinsey Global Institute.2017

[2] D.V. Ponomarenko. Regional informatization as a factor of sustainable development of the territory / Informatization and communication. 2011. No. 4. Page 6-9.

[3] V.V. Droshnev. Informatization - the innovation element of development of economy of the region / the Innovative development of economy: trends and prospects. 2016. T. 1. Page 35-47.

[4] Cann O. New Focus Needed to Raise Global Competitiveness. Weforum. [Electronic https://www.weforum.org/press/2017/09/new-focus-needed-toraiseglobal-competitivenes the USA and the United Kingdom are the leaders of ratings. Voice.

[Electronic

resource].URL: http://www.wipo.int/pressroom/ru/articles/2017/article_0006.html.

[6] Neogronte, N.(1995) Being Digital Knopf (Paper edition 1996, Vintage Books)

[7] V.V. Droshnev. Informatization - the innovation element of development of the region economy / the Innovative development of economy: trends and prospects. 2016. T. 1. Page 35-47.

[8] Milenkovic, M.J., Brajovic, B., Milenkovic, D., Vukmirovic, D., \& Jeremic, V. (2016). Beyond the equalweight framework of the Networked Readiness Index: a multilevel I-distance methodology. Information Development, 32(4), 1120-1136.

[9] European Commission. (2015). Digital Single Market: Bringing Down Barriers to Unlock Online Opportunities. Retrieved from: http://ec.europa.eu/priorities/digital-single-market_en. Accessed 29/09/2018.

[10] Monitoring of regional informatization of the Ministry of digital development, communication and mass communications of the Russian Federation. https://digital.gov.ru/ru/documents/4949/

[11] Alexsandr S. Kuznetsov. Russian Professor's meeting. Russian Journal of Physical Education and Sport. 2019, 14(1), pp. 17-22. DOI: 10.14526/2070-4798-2019-14-1-18-24

[12] Digital Russia index. Skolkovo Moscow School of Management. https://finance.skolkovo.ru/ru/sfice/research-reports/1779-2019-04-22/ 